\title{
In situ demonstration of tissue proliferative activity using anti-bromo-deoxyuridine monoclonal antibody
}

\author{
S VERONESE, * M GAMBACORTA,* B FALINI \\ From the *Istituto di Anatomia Patologica, Ospedale di Niguarda, Milan, Italy, and the Laboratorio di \\ Ematopatologia, Clinica Medica I, Policlinico Monteluce, Perugia, Italy
}

SUMMARY Immunohistochemical staining with anti-bromo-deoxyuridine (BrdU) monoclonal antibody was performed on a variety of human tissues following in vitro incubation with BrdU. The effect of different fixatives and DNA denaturation techniques on the reactivity with anti-BrdU was investigated. Optimal preservation of the antigenicity of BrdU incorporated into the DNA of proliferating cells was seen in tissues fixed in Bouin's fluid, while samples which had been fixed with cross-linking reagents, such as formalin, were usually unreactive. Positivity for BrdU was restored in formalin fixed tissues after digestion with pepsin, but this was usually associated with loss of morphological details. Acid and thermal DNA denaturation techniques gave similar results.

It is concluded that Bouin fixation followed by acid or thermal denaturation of DNA is the method of choice for the in situ detection of cells in S-phase using anti-BrdU monoclonal antibody.

The determination of the percentage of neoplastic cells in S-phase (labelling index) provides useful information on the aggressiveness of individual tumours. This has traditionally been achieved by showing the presence of $3 \mathrm{H}$-thymidine by autoradiography after its incorporation into DNA. The wide application of this method, however, has been limited by the risk of radiotoxicity and the time required for its completion (at least three to six days). A more practical approach relies on the use of monoclonal antibodies (directed against a thymidine analogue-for example, the 5bromo, 2'deoxyuridine (BrdU) monoclonal antibody ${ }^{12}$ after its incorporation into the DNA of proliferating cells. $^{3-7}$ This has usually been achieved by incubating cell suspensions of neoplastic cells with BrdU. ${ }^{8-11}$ But this approach suffers from the drawback that the structure of the tissue is destroyed. To overcome this problem several authors have analysed the in situ distribution of $\mathrm{BrdU}$ positive cells in mouse and human tissues, removed after "in vivo" injection of BrdU. ${ }^{12-14}$ This method, however, can be used only on selected categories of patients. This paper reports the investigation of the suitability of an "in vitro" BrdU incorporation method for the in situ detection of cells in S-phase using the anti-BrdU monoclonal antibody.

\section{Material and methods}

Tissue samples were taken from untreated patients

Accepted for publication 12 January 1989 with breast carcinoma ( $\mathrm{n}=12)$, Hodgkin's disease $(n=3)$, carcinoma of the colon $(n=6)$, malignant fibrous histiocytoma $(n=1)$ and from three bone marrow biopsy specimens (one multiple myeloma and two lymphoplasmacytic immunocytomas). Samples from normal human tonsils $(n=5)$ were also studied. Part of each specimen was processed for routine diagnosis; multiple, fresh fragments were used for BrdU incorporation.

Each sample was minced into multiple fragments (about $1 \mathrm{~mm}^{3}$ ) and placed into $\alpha$-MEM (alpha modification of Eagle's Minimum Essential Medium, Flow Laboratories, Irvine, California, USA) containing $20 \mu \mathrm{M}$ 5-fluoro,2'deoxyuridine (Sigma Chemicals Co, St Louis, Missouri, USA) to block endogenous thymidilate synthesis. After 15 minutes of incubation at $37^{\circ} \mathrm{C}$ in a shaker bath 5-bromo-2'deoxyuridine (Sigma) at a concentration of $10 \mu \mathrm{M}$ was added and further incubated for 60 minutes. The incorporation was stopped by putting the tubes in ice and washing the samples in cold Tris- $\mathrm{HCl}$ buffer (TBS $0.05 \mathrm{M}$, $\mathrm{pH} \mathrm{7.4).}$

After incubation about 30-32 fragments were randomly fixed in four different solutions (seven to eight fragments for each fixative): (1) buffered formalin for four hours; (2) Bouin's solution for two hours; (3) Zenker-acetic acid for six hours; and (4) B5 for two to four hours. After fixation the samples were put into $70 \%$ ethanol and then embedded in paraffin wax. Tissue sections were cut at $5 \mu \mathrm{m}$, 
deparaffinised through graded alcohols, and rehydrated with TBS before being immunostained.

Sections fixed in Bouin's solution and formalin were digested at different pepsin concentrations $(0.05$ and $0.5 \mathrm{mg} / \mathrm{ml}$ ) as previously described by Shutte et al..$^{15}$ All digestions were performed at $37^{\circ} \mathrm{C}$ for five minutes.

\section{DNA DENATURATION}

Three different denaturation methods were used, with a slight modification of the procedure proposed by Dolbeare et al ${ }^{16}$ :

1 Acid denaturation: sections were incubated with $2 \mathrm{~N}$ $\mathrm{HCl}$ for 30 minutes at room temperature and then washed in distilled water and TBS.

2 Basic denaturation: tissue sections were incubated for 60 seconds with $0.07 \mathrm{M} \mathrm{NaOH}$ at room temperature and then washed in distilled water and TBS.

3 Thermal denaturation: sections were treated with $0 \cdot 1 \mathrm{M} \mathrm{HCl}$ for 15 minutes and then washed in TBS. Incubation with $50 \% \mathrm{~N}$, N-dimethylformamide in TBS was performed in a heated oven at $70^{\circ} \mathrm{C}$ for 45 minutes. All sections were then washed in distilled water and TBS.

IMMUNOSTAINING WITH ANTI-BRDU

Endogenous peroxidase activity was blocked by incubation in methanol containing $0.3 \% \mathrm{H}_{2} \mathrm{O}_{2}$ for 30 minutes; DNA denaturation was then performed. The slides were incubated for one hour with anti-BrdU (Becton Dickinson, Mountain View, California, USA) diluted $1 / 20$-about $5 \mu \mathrm{g}$ IgG final concentration-in TBS containing $1 \%$ bovine serum albumin (BSA) and $0.5 \%$ Tween 20 . The next step was incubation with biotin-conjugated rabbit anti-mouse IgG (Vector Laboratories, Burlingame, California, USA) for $\mathbf{3 0}$ minutes followed by avidin-biotin peroxidase conjugation (Vector Laboratories) for $\mathbf{4 5}$ minutes. After two washes in TBS the antibody binding sites were visualised by reaction with filtered diaminobenzidine $(0.5 \mathrm{mg} / \mathrm{ml})$ in TBS containing $0.7 \% \mathrm{H}_{2} \mathrm{O}_{2}$. Slides were counterstained in Harris-Mayer's haematoxylin for 15 seconds and mounted in Eukitt.

Because the inhibition of endogenous peroxidase is not easy to obtain in bone marrow samples, the APAAP procedure ${ }^{17}$ was used to assess the percentage of cells in S-phase in the three bone marrow trephine biopsy specimens.

\section{DOUBLE IMMUNOENZYMATIC STAINING}

Double staining was performed on breast tissue using a sequential staining procedure. ${ }^{18}$ Briefly, tissue sections from breast cancers were firstly stained by the avidin-biotin method for BrdU and then by the APAAP technique for cytokeratins (AE1/AE3, Hybritech, San Diego, California, USA). Lymph node tissue from a patient with Hodgkin's disease was double stained for $\mathrm{BrdU}$ and $\mathrm{Ki}-1$ (CD-30) (Dakopatts, Denmark).

The determination of the BrdU labelling index was performed by scoring no fewer than 3000 neoplastic cells from different fragments of the same tumour (at a magnification of 1000 times). The percentage value was obtained by dividing the number of positive cells by the total number of cells. The different sections could be compared for BrdU because BrdU penetration took place homogeneously on the various surfaces of the fragments and the counting was limited to the peripheral areas of the section.

\section{Results}

The results obtained by using different fixatives and DNA denaturation methods are summarised in table 1. The strongest reactivity with anti-BrdU was observed in tissues fixed in Bouin's solution (figs la-f). Variable reactivity was observed in tissues fixed in B5 and Zenker-acetic acid, while those fixed in formalin were consistently negative.

DNA denaturation methods did not influence the results obtained with tissues fixed in Bouin's solution and formalin, while BrdU reactivity in tissues fixed in

Table 1 Schematic representation of anti-BrdU reactivity after different fixation and DNA denaturation methods

\begin{tabular}{|c|c|c|c|c|c|c|c|c|c|c|c|c|c|}
\hline \multirow[b]{3}{*}{ Specimen } & \multirow[b]{3}{*}{ No of cases } & \multicolumn{12}{|c|}{ Fixatives } \\
\hline & & \multicolumn{3}{|c|}{ Bouin's fluid } & \multicolumn{3}{|l|}{ B 5} & \multicolumn{3}{|c|}{ Zenker acetic acid } & \multicolumn{3}{|c|}{ Formalin } \\
\hline & & $*$ Acid & Basic & Thermal & Acid & Basic & Thermal & Acid & Basic & Thermal & Acid & Basic & Thermal \\
\hline $\begin{array}{l}\text { Normal tonsil } \\
\text { †Bone marrow } \\
\text { Breast carcinoma } \\
\text { Hodgkin's lymphoma } \\
\text { Colon carcinoma } \\
\text { Malignant histiocytoma }\end{array}$ & $\begin{array}{r}5 \\
3 \\
12 \\
3 \\
6 \\
1\end{array}$ & $\begin{array}{l}+ \\
+ \\
+ \\
+ \\
+ \\
+\end{array}$ & $\begin{array}{l}+ \\
+1- \\
+ \\
+ \\
+1- \\
+1-\end{array}$ & $\begin{array}{l}+ \\
+ \\
+ \\
+ \\
+ \\
+\end{array}$ & $\begin{array}{l}+ \\
\text { ND } \\
+1- \\
+1- \\
+1- \\
+1-\end{array}$ & $\begin{array}{l}- \\
- \\
- \\
-\end{array}$ & $\begin{array}{l}- \\
+1- \\
+1- \\
+1- \\
+1-\end{array}$ & $\begin{array}{l}+1- \\
\text { ND } \\
+1- \\
- \\
+1- \\
+1-\end{array}$ & $\begin{array}{l}- \\
- \\
- \\
-\end{array}$ & $\begin{array}{l}+1- \\
+1- \\
\overline{+1-} \\
+1-\end{array}$ & $\begin{array}{l}- \\
\text { ND } \\
- \\
- \\
-\end{array}$ & $\begin{array}{l}- \\
- \\
- \\
-\end{array}$ & $\begin{array}{l}- \\
- \\
- \\
-\end{array}$ \\
\hline
\end{tabular}

*DNA denaturations.

Tissue sections were scored as positive ( + : strong dark brown labelling), weak ( + / - : light brown labelling) and negative $(-)$

†One case of multiple myeloma and two of lymphoplasmacytic immunocytoma 


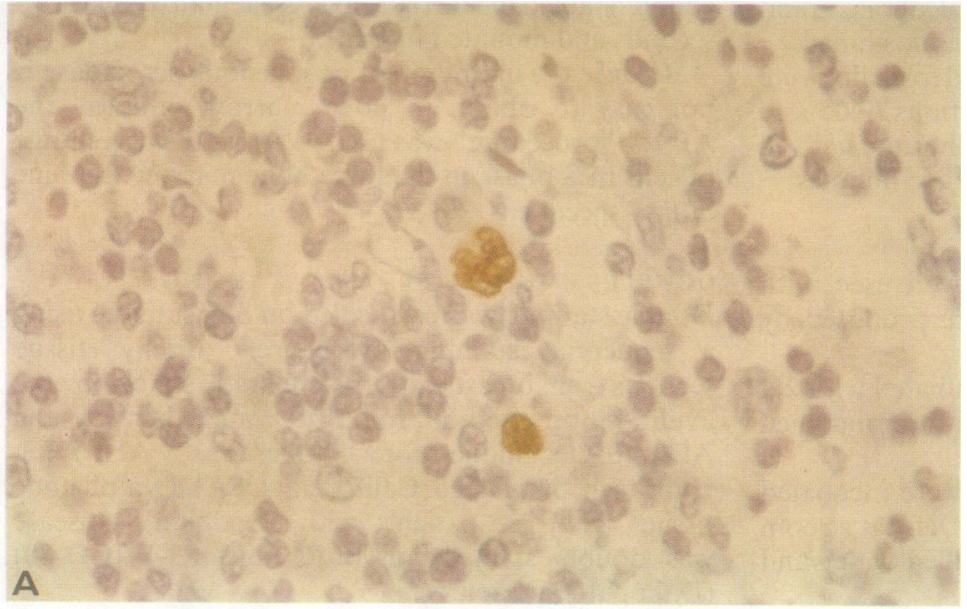

(b)

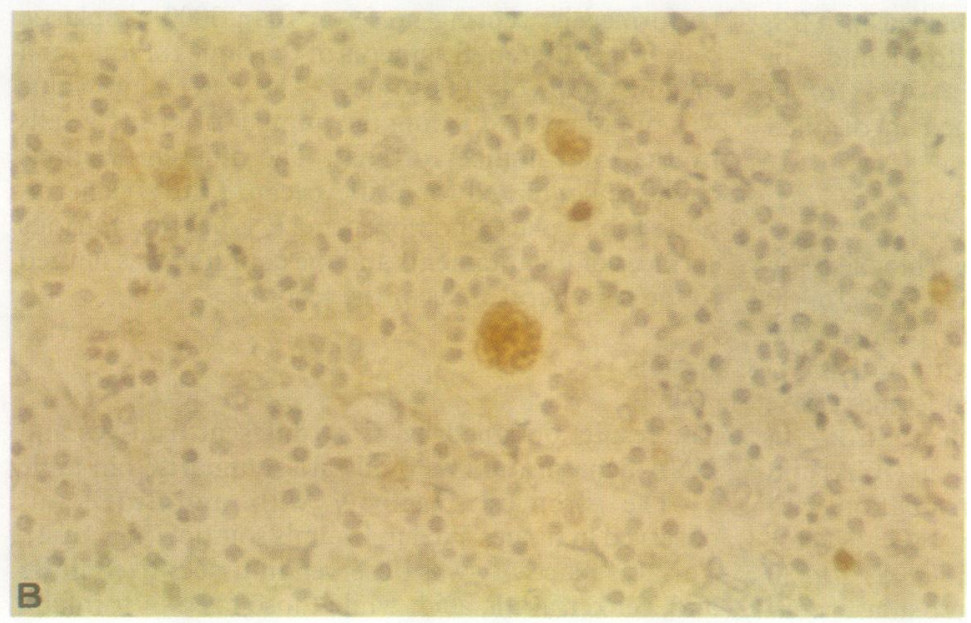

Fig 1 Reactivity with anti-BrdU in tissues fixed in Bouin's solution following acid (a, c, e) and thermal $(b, d, f) D N A$ denaturation.

( $a$ and $b$ ) Hodgkin's disease with labelled Reed-Sternberg cells. (Avidin-biotin technique.)

(c) Ductal infiltrating breast carcinoma. (Avidin-biotin technique.)

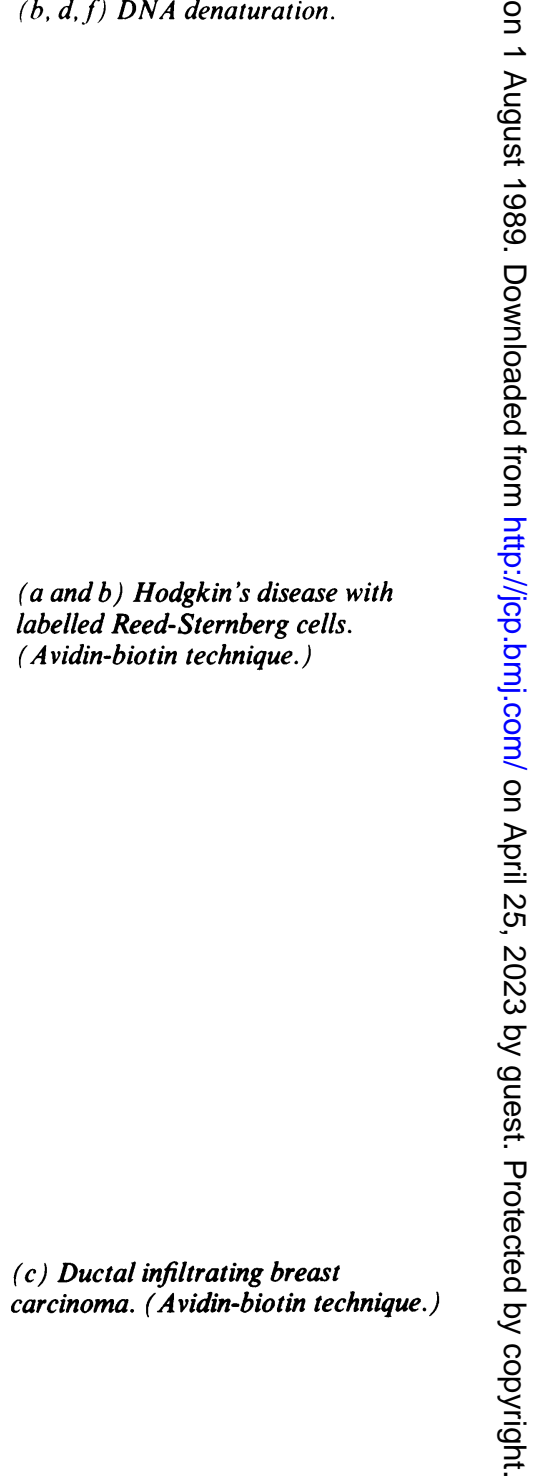




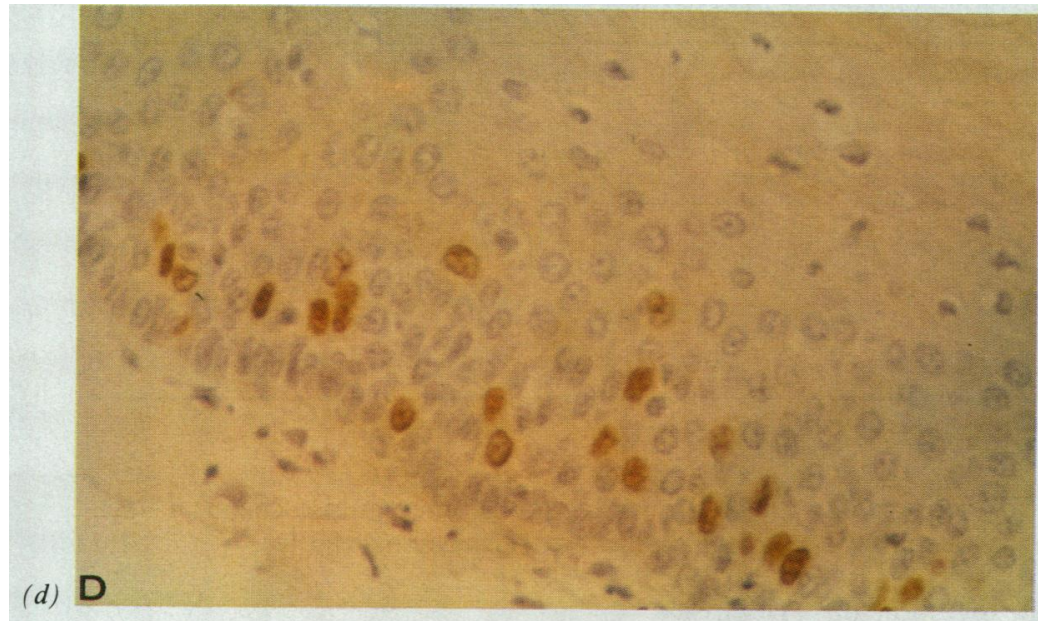

(d) Hyperplastic tonsil with basal layer of the epidermis rich in $S$-phase cells. (Avidin-biotin technique.)

(e)

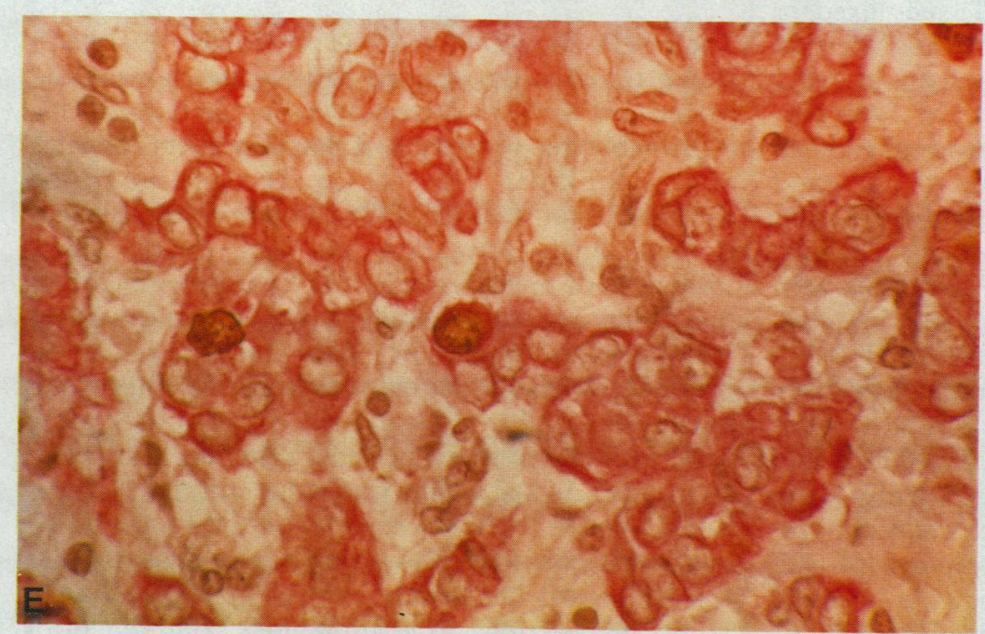

(f)

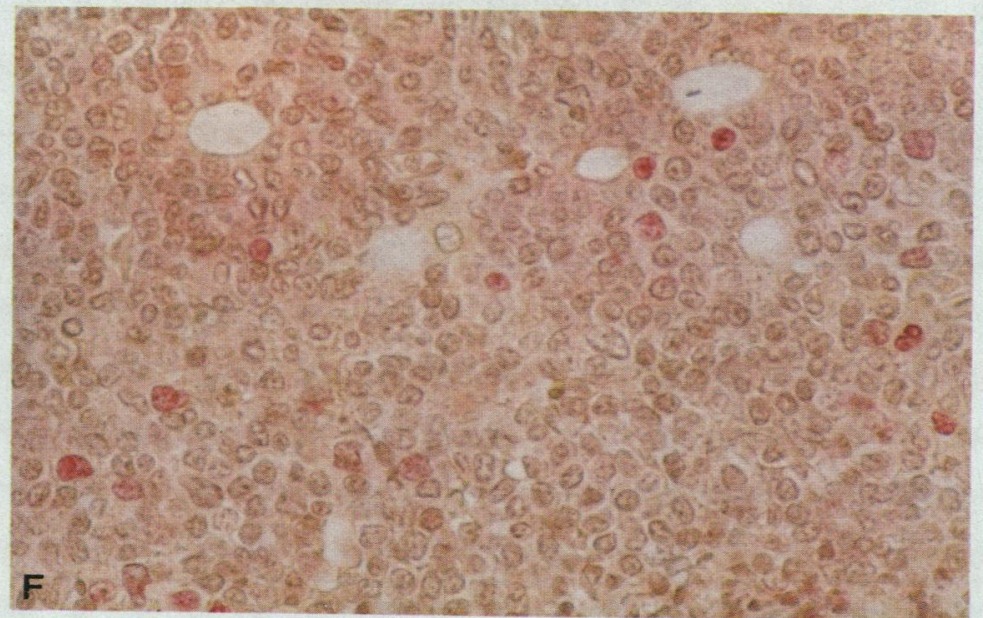


Table 2 Improvement in BrdU reactivity after pepsin digestion in tissues fixed in Bouin's fluid and formalin

\begin{tabular}{|c|c|c|c|c|c|c|c|}
\hline \multirow[b]{3}{*}{ Specimen } & & \multirow[b]{3}{*}{ No of cases } & \multicolumn{2}{|l|}{ Bouin's fluid } & \multicolumn{3}{|l|}{ Formalin } \\
\hline & & & \multirow{2}{*}{$\begin{array}{l}\text { No proteolytic } \\
\text { treatment }\end{array}$} & \multirow{2}{*}{$\begin{array}{l}\text { Pepsin digestion } \\
(0.05 \mathrm{mg} / \mathrm{ml})\end{array}$} & \multirow{2}{*}{$\begin{array}{l}\text { No proteolytic } \\
\text { treatment }\end{array}$} & \multicolumn{2}{|c|}{ Pepsin digestion } \\
\hline & & & & & & $0.05 \mathrm{mg} / \mathrm{ml}$ & $0.5 \mathrm{mg} / \mathrm{ml}$ \\
\hline \multirow{2}{*}{ Breast carcinoma } & ${ }^{*}$ Acid & \multirow{2}{*}{12} & + & + & - & - & + \\
\hline & Thermal & & + & + & - & - & + \\
\hline \multirow{2}{*}{ Hodgkin's disease } & Acid & \multirow{2}{*}{3} & + & + & - & $+1-$ & + \\
\hline & Thermal & & + & + & - & $+1-$ & + \\
\hline
\end{tabular}

*DNA denaturation

B5 and Zenker-acetic acid was better following acid and thermal denaturation than with basic denaturation.

Table 2 shows the effect of pepsin digestion on mammary and lymphnode tissues. Tissues fixed in Bouin's solution and treated with acid and thermal denaturation did not show any improvement in BrdU reactivity following pepsin digestion. In formalinfixed tissues the use of pepsin at the concentration of $0.05 \mathrm{mg} / \mathrm{ml}$ produced weak BrdU reactivity; good reactivity was reached with $0.5 \mathrm{mg} / \mathrm{ml}$ of pepsin treatment. The preservation of morphological details, however, was not as good as that achieved with Bouin's fluid.

The results obtained with anti-BrdU and $\mathrm{Ki}-67$ monoclonal antibodies in 12 patients affected by breast carcinoma showed large variations in range of values (BrdU: 0.01\%-5.41\%; Ki-67: 2\%-73\%), and for each tumour BrdU values were consistently lower than those for $\mathrm{Ki}-67$ (table 3). A correlation was observed, however, between the percentage of cells positive for BrdU and $\mathrm{Ki}-67$ : an increase in BrdU values was always associated with an increase in $\mathrm{Ki}-67$ values.

The epithelial nature of BrdU positive cells was clearly shown by double immunohistochemical staining in a case of breast carcinoma (fig le).

\section{Discussion}

The results show that without proteolytic treatment, Bouin's fluid is the optimal fixative for showing the presence of BrdU positive cells in human tissues. This is prohably due to its lack of masking effects on sites reactive for BrdU. This fact may be explained by the combined fixative effect of the different constituents of Bouin's fluid: formation of salts (picric acid); formation of methylene cross-links between different functional groups (formalin); and modification of nucleoprotein hydration state (acetic acid). In contrast, formalin fixation radically changed the antigenicity of $\mathrm{BrdU}$ incorporated into proliferating cells, probably due to the masking effect of protein cross-links. In agreement with other authors, ${ }^{16}$ it was found that the reactivity of formalin-fixed tissues with anti-BrdU could be restored by pepsin digestion but the cytological details were less well preserved than in undigested sections fixed in Bouin's solution. Both acid and thermal denaturations of DNA gave optimal immunohistochemical staining results.

Table 3 Immunohistochemical evaluation of proliferative features in breast carcinoma

\begin{tabular}{|c|c|c|c|c|}
\hline Case No & Diagnosis & Menopausal state & $\begin{array}{l}\text { BrdU } \\
\text { Positive cells } \\
(\%)\end{array}$ & $\begin{array}{l}\text { Ki-67 } \\
\text { Positive cells } \\
(\%)\end{array}$ \\
\hline $\begin{array}{l}1 \\
2 \\
3 \\
4 \\
5 \\
6 \\
7 \\
8 \\
9 \\
10 \\
11 \\
12\end{array}$ & $\begin{array}{l}\text { Lobular infiltrating carcinoma } \\
\text { Ductal infiltrating carcinoma } \\
\text { Medullary carcinoma } \\
\text { Ductal infiltrating carcinoma }\end{array}$ & $\begin{array}{l}\text { Post } \\
\text { Post } \\
\text { Post } \\
\text { Post } \\
\text { Post } \\
\text { Post } \\
\text { Pre } \\
\text { Post } \\
\text { Post } \\
\text { Pre } \\
\text { Pre } \\
\text { Post }\end{array}$ & $\begin{array}{l}0.01 \\
0.31 \\
0.42 \\
0.81 \\
1.30 \\
1.56 \\
1.94 \\
2.48 \\
2.95 \\
3.47 \\
4.85 \\
5.41\end{array}$ & $\begin{array}{r}2 \\
7 \\
5 \\
5 \\
20 \\
10 \\
20 \\
25 \\
40 \\
43 \\
53 \\
73\end{array}$ \\
\hline
\end{tabular}

*The percentage numbers represent the average value obtained by scoring seven different areas of the sections 
The method described offers several advantages over the traditional BrdU "in vitro" incorporation method in cell suspension. ${ }^{815}$ First, it permits the preservation of the tissue structure and, therefore, the recognition of the topographical distribution of labelled cells-for example, foci of proliferating cells in a "resting" population.

Secondly, it seems to be the only method available for the assessment of the percentage of cells in S-phase when only small tissue samples are available-for example, skin, bronchial, or gastrointestinal biopsy specimens - or when no marrow particles can be aspirated ("dry tap"), a common situation in myelofibrotic or packed bone marrows.

The data also show that double immunostaining can be performed on paraffin wax sections by using monoclonal antibodies directed against BrdU and epitopes of epithelial (cytokeratins) and lymphoidassociated molecules (CD 30) resistant to fixatives. This procedure is effective in defining the phenotype of proliferating elements in the context of a mixed cell population such as that found in Hodgkin's disease.

Results similar to the method described have been achieved by in vivo infusion of BrdU followed by tissue sampling one to five hours later.$^{89}$ But, although it has been claimed that $\mathrm{BrdU}$ is neither radioactive nor myelotoxic, its use in vivo is ethically applicable only to selected categories of patients.

Immunostaining of frozen sections with the $\mathrm{Ki}-67$ monoclonal antibody ${ }^{19}$ has proved a highly effective method for the in situ identification of proliferating cells in a variety of human tissues. ${ }^{17}$ This reagent, however, is not specific for cells in S-phase because it recognises a proliferation-associated antigen expressed in all the cell cycle phases except G0 and early G1. ${ }^{20}$ Moreover, it is only applicable to frozen sections in which cytological details are usually poorly preserved.

The in situ method described provides complementary data to Ki-67 immunostaining: the results in breast tumours show a linear association between BrdU and Ki-67 positive cells. We suggest that antiBrdU and anti-Ki-67 monoclonal antibodies should possibly be used in combination to achieve a better definition of the kinetic features of individual tumours.

The main drawback of the BrdU technique is that nuclear labelling is only evident up to a depth of 100 $\mu \mathrm{m}$ from the cut surface: for this reason the area taken into consideration for the score was limited to the periphery of each section. Moreover, we did not observe further positivity in the inner parts of the sections, even by increasing BrdU concentration or lengthening the incubation time. The same observations were reported by Titus et al in autoradiographic studies with $3 \mathrm{H}$-thymidine. ${ }^{21}$ In contrast, an increased depth of $3 \mathrm{H}$-thymidine labelling was obtained when

the samples were treated in hyperbaric chambers. ${ }^{22}$

In conclusion, our results indicate that it is possible to study the percentage of cells in S-phase in human tissues following in vitro incubation with BrdU. This in situ identification of S-phase cells, associated with other proliferation markers, such as $\mathrm{Ki}-67$, could provide useful information about the cell kinetics of human tumours and could be of value in planning the most appropriate patient management.

We thank Mrs S Piovan, Miss C Maisano, and Miss $\mathbf{R}$ Dadati for their skilled technical assistance.

\section{References}

1 Gratzner HG. Monoclonal antibody to 5-bromo and 5-iododeoxyuridine: a new reagent for detection of DNA replication. Science 1982;218:474-5.

2 Raza A, Preisler HD, Mayers GL, Bankert R. Rapid enumeration of S-phase cells by means of monoclonal antibodies. $N$ Engl $J$ Med 1984;310:991.

3 Eidinoff ML, Knoll JE, Marano BJ, Klein D. Pyrimidine studies. II. Effect of 5-bromodeoxyuridine and related nucleosides on incorporation of precursors into nucleic acid pyrimidines. Cancer Res 1959;19:738-45.

4 Latt SA. Fluorometric detection of deoxyribonucleic acid synthesis: possibilities for interfacing bromodeoxyuridine dye techniques with flow fluorometry." $J$ Histochem Cytochem 1977;25:913-26.

5 Pera F, Mattias P, Detzer K. Methods for determining the proliferation kinetics of cells by means of 5-bromodeoxyuridine. Cell Tissue Kinet 1977;10:255-64.

6 Kriss JP, Revesz L. Quantitative studies of incorporation of exogenous thymidine and 5-bromodeoxyuridine into DNA of mammalian cells in vitro. Cancer Res 1961;21:1141-7.

7 Darzynkiewicz Z, Andreeff M, Traganos F, Sharpless T, Melamed MR. Discrimination of cycling and non-cycling lymphocytes by BrdU suppressed acridine orange fluorescence in a flow cytometric system. Exp Cell Res 1978;115:81-5.

8 Wilson GD, McNally NJ, Dunphy E, Karcher H, Pfragner R. The labelling index of human and mouse tumors assessed by bromodeoxyuridine staining in vitro and in vivo and flow cytometry. Cytometry 1985;6:641-7.

9 Raza A, Ucar K, Preisler HD. Double labeling and in vitro versus in vivo incorporation of bromodeoxyuridine in patients with acute non-lymphocytic leukemia. Cytometry 1985;6:633-40.

10 Boccadoro M, Redoglio W, Gavarotti P, Pileri A. Multiple myeloma plasma cell kinetics: rapid and reliable evaluation using 5-bromo, 2 deoxyuridine (BrdUrd) DNA incorporation detected by an anti-BrdUrd monoclonal antibody. Tumori 1986;72:135-7.

11 Falini B, Canino S, Sacchi S, et al. Immunocytochemical evaluation of the percentage of proliferating cells in pathological bone marrow and peripheral blood samples with $\mathrm{Ki}-67$ and antibromodeoxyuridine monoclonal antibodies. $\mathrm{Br} \mathrm{J}$ Haematol 1988;69:311-20.

12 Hoshino T, Nagashima T, Murovic J, Levin ME, Levin VA, Rupp SM. Cell kinetic studies of in situ human brain tumors with bromodeoxyuridine. Cytometry 1985;6:627-32.

13 Hoshino T, Nagashima T, Cho Kg, et al. S-phase fraction of human brain tumors in situ measured by uptake of bromodeoxyuridine. Int J Cancer 1986;38:369-74.

14 Shutte B, Reinders MMJ, Bosman FT, Blijham GH. Studies with antibromodeoxyuridine antibodies. II. Simultaneous detection of antigen expression and DNA synthesis by in vivo labeling of 
mouse intestinal mucosa. J Histochem Cytochem 1987;35: $371-4$.

15 Shutte B, Reinders MMJ, Bosman FT, Blijham GH. Effect of tissue fixation on anti-bromodeoxyuridine immunochemistry. J Histochem Cytochem 1987;35:1343-5.

16 Dolbeare F, Beisker W, Pallavicini MG, Vanderlaan M, Gray JM. Cytochemistry for bromodeoxyuridine/DNA analysis: stoichiometry and sensitivity. Cytometry 1985;6:521-30.

17 Cordell JI, Falini B, Erber W, et al. Immunoenzymatic labeling of monoclonal antibodies using immune complexes of alkaline phosphatase and monoclonal anti-alkaline phosphatase (APAAP complexes). J Histochem, Cytochem 1984;32:219-29.

18 Falini B, Abdulaziz Z, Gerdes J, et al. Description of sequential staining procedure for double immunoenzymatic staining of pairs of antigens using monoclonal antibodies. I Immunol Methods 1986;93:265-73.
19 Gerdes J, Schwab V, Lemke H, et al. Production of a mouse monoclonal antibody reactive with a human nuclear antigen associated with cell proliferation. Int J Cancer 1983:31:13-20.

20 Gerdes J, Lemke $\mathrm{H}$, Baish $\mathrm{H}$, et al. Cell cycle analysis of a cell proliferation-associated nuclear antigen defined by the monoclonal antibody Ki-67. J Immunol 1984;133:1710-15.

21 Titus JL, Shorter LG. Labeling of human tumors with tritiated thymidine. Archives of Pathology 1965;79:324-8.

22 Meyer JS, Connor RE. In vitro labeling of solid tissues with tritiated thymidine for autoradiographic detection of S-phase nuclei. Stain Technol 1977;52:185-95.

Requests for reprints to: Dr S Veronese, Istituto di Anatomia Patologica, Ospedale di Niguarda-Ca'Granda Piazza Ospedale Maggiore 3, 20165 Milan, Italy. 